九州大学学術情報リポジトリ

Kyushu University Institutional Repository

\title{
Performance Assessment of Existing Korean School Builiding (I) : Mechanical and Physical Properties of the Rafter Members
}

\section{Kim, Gwang-Chul}

Department of Housing environmental design, College of Human Ecology, Chonbuk National University

\section{Kang, Chun-Won}

Department of Housing environmental design, College of Human Ecology, Chonbuk National University

Matsumura, Junj i

Laboratory of Wood Science, Department of Forest and Forest Product Science, Faculty of Agriculture, Kyushu University

https://doi.org/10.5109/16127

出版情報: 九州大学大学院農学研究院紀要. 54 (2)，pp.439-444，2009-10-29. Faculty of Agriculture, Kyushu University バージョン：

権利関係 : 


\title{
Performance Assessment of Existing Korean School Building (I) - Mechanical and Physical Properties of the Rafter Members -
}

\author{
Gwang-Chul KIM*1, Chun-Won KANG ${ }^{1}$ \\ and Junji MATSUMURA ${ }^{2}$
Laboratory of Wood Science, Department of Forest and Forest Product Science, Faculty of Agriculture, Kyushu University, Fukuoka 812-8581, Japan \\ (Received June 30, 2009 and accepted July 13, 2009)
}

\begin{abstract}
Many potentially valuable wood residues from buildings are ending up as broken-up waste destined for the landfills in Korea. This practice is a significant economic loss. An accurate estimation of residual capacities of the lumber found in older structures is required prior to the promotion of the reuse and recycle ratio. For this purpose, precursor studies are required on the accurate assessment of residual capacities according to time for typical construction species used in Korea. The case study for this current research is the rafter members of the Iksan national college educational building in Korea. The age of the rafter members is estimated to be 50 years. 196 sample specimens were visually divided into two groups according to annual ring and cross-section features.

From the results of this study, the following conclusions have been made:

1. The moisture content of group 1 was found to be slightly higher than that of group 2 . In the case of oven-dried density, the averages between the two groups were almost the same.

2. The strength values of group 2 were all higher than those of group 1 with the exception of shear strength. It is assumed that the domestic major construction species is a type of hard pine according to the obtained physical and mechanical properties, and visual characteristics.

3. The main fracture mode of group 1 is that of cross grain tension. In the case of group 2 , the fracture modes are distinguished by a mixed mode rather than by one type of mode. Failure types for compressive strength are all of a crushing failure type with the exception of the splitting failure type for specimen 7 in group 2.

4. There were no significant differences between the two groups in terms of mechanical properties. However, there was an obvious visual difference between the two groups.
\end{abstract}

Keywords: residual capacity, moisture content, fracture mode, mechanical properties

\section{INTRODUCTION}

In Korea, innumerable residential wooden structures were built from sawn lumber and timber during the end of the decade. Many wood-framed complex structures were also built after the restoration of independence from Japan. Specially, almost all of the buildings that were constructed after this time were built with a wooden roof frame. However, many potentially valuable wood materials from these buildings are ending up as broken-up waste destined for the landfills in Korea. This practice is a significant economic loss. Therefore, many opportunities to reuse these materials could be possible provided that the true mechanical properties of the lumber found in these older structures can be determined by an accurate species analysis and residual capacity assessment. For example, for secondary members in wood-framed constructions, where special safety is not required, materials can be reused for the manufacture of antique furniture and can be reprocessed as eco-interior materials. Specifically, because the timber used for the members of

\footnotetext{
1 Department of Housing environmental design, College of Human Ecology, Chonbuk National University, Jeonju 561-756, Korea

2 Laboratory of Wood Science, Department of Forest and Forest Product Science, Faculty of Agriculture, Kyushu University, Fukuoka 812-8581, Japan

* Corresponding author (E-mail: gckim@chonbuk.ac.kr)
}

these wood-framed complex structures was untreated, they can be utilized for many reused and recycled ecomaterials that require minimal structural performance.

Nonetheless, an accurate estimation of residual capacities of the lumber found in older structures is required prior to the promotion of the reuse and recycle ratio. For this purpose, precursor studies are required on the accurate assessment of residual capacities according to time for typical construction species used in Korea. Unfortunately, such studies associated with residual capacities for existing structures have not been carried out.

The case study for this current research is the rafter members of the Iksan national college educational building in Korea. The roof system of the building has been recently remodeled. A sequence of studies has been carried out by the author on an assessment of the residual capacities of lumber found in this older structure.

The age of the rafter members is estimated to be 50 years. From a visual inspection, the members were categorized into two groups. An assessment of the mechanical and physical properties of the lumber found in the structure was initially carried out. An analysis of variance was conducted to determine if the test results varied between the two groups. The differences were tested to determine if they were significant at the level of 95 percent. 


\section{MATERIALS AND METHODS}

The target building for this current research is the educational building of Iksan National College in Korea. The building has been used as a lecture hall since 1959 . The age of the rafter members is therefore estimated to be 50 years. The building is of a mixed structural type, with stone, wood and brick. In 2007, the building was remodeled for the installation of a heating and air-conditioning system. The rafter members in the roof frame were procured for this study.

There were a total of 196 pieces as sample specimens. These 196 rafters were visually divided into two groups according to annual ring and cross-sectional features. (Group I: 99, group II: 97) Group I had straight and dense a grain of wood than that of group II. And group I had a narrow width of annual ring than that of group II. Also, group I showed a sudden transition of earlywood to latewood and had a wide width than that of group II. Accordingly, group I had a coarse texture than that of
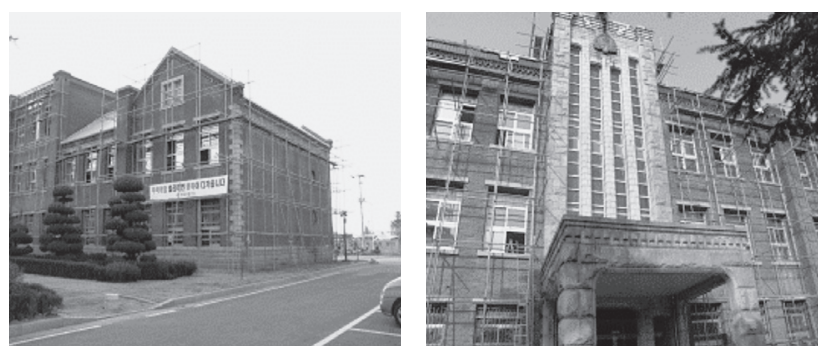

Fig. 1. The target building for current research.
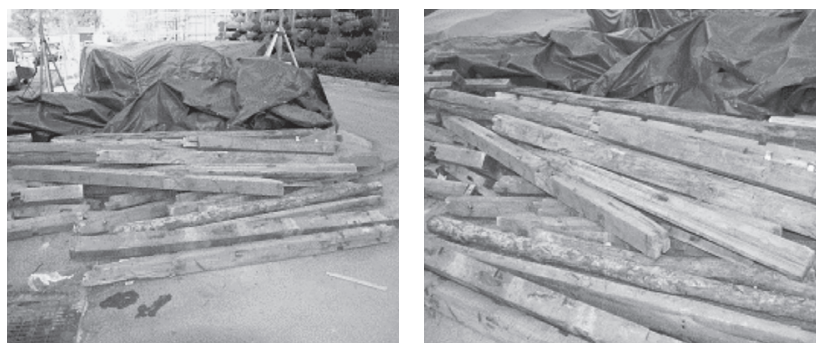

Fig. 2. Photos of rafter members.

Table 1. The size and number of rafter members by group

\begin{tabular}{ccccc}
\hline & $\begin{array}{c}\text { Depth } \\
(\mathrm{mm})\end{array}$ & $\begin{array}{c}\text { Width } \\
(\mathrm{mm})\end{array}$ & $\begin{array}{c}\text { Length } \\
(\mathrm{cm})\end{array}$ & No. \\
\hline Group 1 & $89-140$ & $88-124$ & $165-376$ & 99 \\
Group 2 & $104-133$ & $114-144$ & $101-367$ & 97 \\
\hline
\end{tabular}
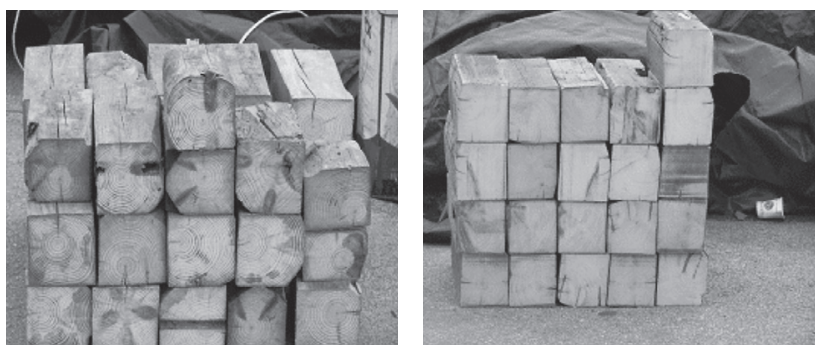

Fig. 3. The cross section cutting specimens of rafter members (Left: group I, Right: group II). group II. Group I were almost yellow or yellowish brown color. while, group II were almost light white color and some silk color. Figure 1 is the target building for current research and Fig. 2 is rafter members of target building. Figure 3 show the cross section cutting specimens of rafter members (Left: group I, Right: group II). The size and number of rafter members by group were presented in Table 1.

Small specimens were cut from the rafter members for moisture content measurement and density determination, in accordance with ASTM D4442-92 and ASTM D2395-02. There were more than 10 examples of each sample specimen, which were $25 \times 25 \times 25 \mathrm{~mm}$ for MC measurement, and $50 \times 50 \times 150 \mathrm{~mm}$ for density determination. To evaluate the mechanical properties of the rafter members, 10 specimens were prepared for each strength category according to ASTM D 143-94. For the compressive strength specimen, the sizes were $25 \times 25 \times 100 \mathrm{~mm}(1 \mathrm{~mm} / \mathrm{min})$, for the bending strength specimen, the sizes were $25 \times 25 \times 410 \mathrm{~mm}(1.3 \mathrm{~mm} / \mathrm{min})$, for the shear strength specimen, the sizes were $50 \times 50 \times 63 \mathrm{~mm}(0.6 \mathrm{~mm} / \mathrm{min})$, and for the tensile strength specimen the length was $460 \mathrm{~mm}$, the thickness of the center was $4.8 \mathrm{~mm}$, and the center length was $63 \mathrm{~mm}(1 \mathrm{~mm} / \mathrm{min})$. A domestic testing machine was used to evaluate the mechanical properties. (R\&B model Unitech $\mathrm{S}^{\mathrm{TM}}$, Maximum load capacity 10 ton).

\section{RESULTS AND DISCUSSION}

\section{Physical properties of the rafter members for each group}

Table 2 shows the physical properties of rafter mem-

Table 2. Physical properties of the rafter members

\begin{tabular}{|c|c|c|c|c|}
\hline \multirow[b]{2}{*}{$\begin{array}{l}\text { Specimen } \\
\text { Number }\end{array}$} & \multicolumn{2}{|r|}{ Group I } & \multicolumn{2}{|c|}{ Group II } \\
\hline & $\begin{array}{l}\mathrm{MC} \\
(\%)\end{array}$ & $\begin{array}{c}\text { Oven-dried } \\
\text { density }\left(\mathrm{g} / \mathrm{cm}^{3}\right)\end{array}$ & $\begin{array}{l}\mathrm{MC} \\
(\%)\end{array}$ & $\begin{array}{c}\text { Oven-dried } \\
\text { density }\left(\mathrm{g} / \mathrm{cm}^{3}\right)\end{array}$ \\
\hline 1 & 16.5 & 0.39 & 14.6 & 0.58 \\
\hline 2 & 23.1 & 0.49 & 15.1 & 0.52 \\
\hline 3 & 23.3 & 0.44 & 15.5 & 0.50 \\
\hline 4 & 23.4 & 0.45 & 15.0 & 0.47 \\
\hline 5 & 17.6 & 0.48 & 15.4 & 0.53 \\
\hline 6 & 23.8 & 0.45 & 14.9 & 0.45 \\
\hline 7 & 17.0 & 0.43 & 15.2 & 0.45 \\
\hline 8 & 22.7 & 0.52 & 16.6 & 0.36 \\
\hline 9 & 23.0 & 0.50 & 15.1 & 0.46 \\
\hline 10 & 26.6 & 0.52 & 17.1 & 0.35 \\
\hline 11 & 23.6 & 0.44 & 14.9 & 0.46 \\
\hline 12 & 23.1 & 0.52 & 17.3 & 0.35 \\
\hline 13 & 23.9 & 0.45 & 15.5 & 0.38 \\
\hline 14 & - & - & 16.7 & 0.35 \\
\hline 15 & - & - & 14.8 & 0.45 \\
\hline Average & 22.1 & 0.47 & 15.6 & 0.44 \\
\hline $\begin{array}{l}\text { Standard } \\
\text { deviation }\end{array}$ & 3.1 & 0.04 & 0.9 & 0.07 \\
\hline
\end{tabular}


bers by visual grouping. The moisture content of group 1 was found to be higher than that of group 2 .

In the case of oven-dried density, the averages were almost the same between the two groups. The ovendried density of rafter members is similar to that of the domestic construction species. According to the physical properties and visual characteristics, Group 1 could be suggested as hard pine (Pinus spp.) and group 2 could be suggested as fir (Abies spp.).

\section{Mechanical properties of rafter members}

Table 3 shows the test results for the mechanical properties of rafter members according to ASTM. All strength values of group 2 were higher than those of group 1 with the exception of shear strength. Considering the density, all strength values of group 1 should be higher than those of group 2. Specifically, almost all the tensile specimens for group 1 were fractured in the vicinity of the tensile grip. It was therefore impossible to obtain accurate tensile strength values. It is assumed that the primary cause on the fracture in the vicinity of the tensile grip is that group 1 had a higher $\mathrm{MC}$ than that of group 2. However, in order to determine more specific reasons, a follow-up study should be carried out. In addition, the tensile strength should be higher than the compressive strength in the standard condition. However, the abnormal fracture in the vicinity of the tensile grip resulted in a lower tensile strength than compressive strength.

The shear strength should be $10 \%$ of the bending strength in a normal condition. Similar results have been obtained in this current study.

At the time when the existing structure was built, in Korea, wood construction members were not treated with preservatives. Furthermore, there were no standards or regulations for the structural design of wood construction members. Such structures have therefore suffered from overload during this time period. It can therefore generally be assumed that rafter members found in older structures have undergone considerable strength reduction. Conversely, rafter members can be reused and recycled for use as eco-interior and antique furniture materials because they were not treated with preservatives.

\section{Fracture modes and failure types of rafter mem- bers}

Fracture modes of bending strength specimens are shown in Table 4, Fig. 5, Fig. 6, and Fig. 7. The main fracture mode of group 1 is the cross grain tension. The remaining fracture modes of simple tension, brash tension, and compression have the same proportion. In the case of group 2, the fracture modes are distinguished by a mixed mode rather than by one type. The most common case was that where a mixed fracture mode of com-

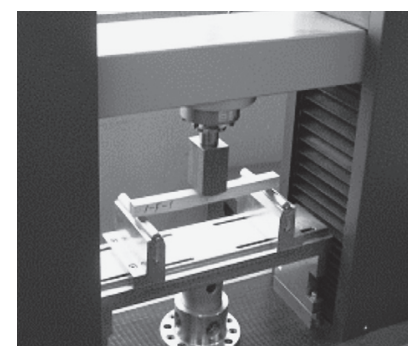

Fig. 4. Testing machine used to evaluate the mechanical properties.
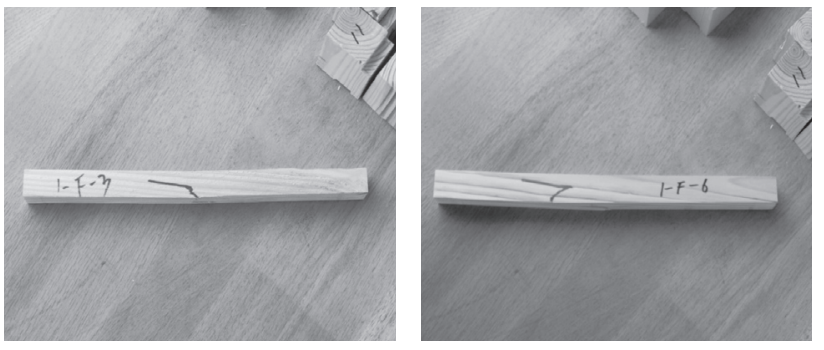

Fig. 5. Fracture mode of bending strength specimen for group 1 .

Table 3. Mechanical properties of the rafter members (MPa)

\begin{tabular}{|c|c|c|c|c|c|c|c|c|}
\hline & \multicolumn{2}{|c|}{$\begin{array}{l}\text { Compressive } \\
\text { strength }\end{array}$} & \multicolumn{2}{|c|}{$\begin{array}{l}\text { Bending } \\
\text { Strength }\end{array}$} & \multicolumn{2}{|c|}{$\begin{array}{l}\text { Shear } \\
\text { strength }\end{array}$} & \multicolumn{2}{|c|}{$\begin{array}{c}\text { Tensile } \\
\text { strength }\end{array}$} \\
\hline & Group I & Group II & Group I & Group II & Group I & Group II & Group I & Group II \\
\hline 1 & 35.9 & 51.5 & 71.9 & 91.9 & 7.0 & 8.0 & 43.6 & 42.3 \\
\hline 2 & 43.8 & 40.8 & 55.7 & 100.7 & 8.5 & 7.3 & 28.6 & 25.4 \\
\hline 3 & 29.8 & 32.2 & 78.7 & 91.7 & 8.5 & 6.9 & 15.1 & 25.2 \\
\hline 4 & 29.8 & 35.3 & 56.4 & 83.6 & 7.9 & 7.3 & - & 40.0 \\
\hline 5 & 34.1 & 34.8 & 85.4 & 65.3 & 9.1 & 8.1 & 24.0 & 46.0 \\
\hline 6 & 26.9 & 46.2 & 80.4 & 79.5 & 9.0 & 7.3 & 26.0 & 24.0 \\
\hline 7 & 42.7 & 39.2 & 91.3 & 84.6 & 9.4 & 7.2 & 23.0 & 29.4 \\
\hline 8 & 42.7 & 44.1 & 73.8 & 98.4 & 5.5 & 7.9 & 24.2 & 30.1 \\
\hline 9 & 37.3 & 30.6 & 60.4 & 64.1 & 6.1 & 7.4 & 9.2 & 40.7 \\
\hline 10 & 29.9 & 39.4 & 71.4 & 79.0 & 6.9 & 6.8 & 23.4 & 25.3 \\
\hline Average & 35.3 & 39.4 & 72.6 & 83.9 & 7.8 & 7.4 & 24.1 & 32.8 \\
\hline $\begin{array}{l}\text { Standard } \\
\text { deviation }\end{array}$ & 6.2 & 6.5 & 12.0 & 12.5 & 1.3 & 0.4 & 9.4 & 8.5 \\
\hline
\end{tabular}


Table 4. Fracture modes of rafter members

\begin{tabular}{|c|c|c|c|c|}
\hline & \multicolumn{2}{|r|}{ Group I } & \multicolumn{2}{|r|}{ Group II } \\
\hline \multirow{10}{*}{$\begin{array}{c}\text { Fracture } \\
\text { Mode }\end{array}$} & 1 & compression & 1 & compression \& cross grain tension \\
\hline & 2 & brash tension & 2 & compression \& simple tension \\
\hline & 3 & cross grain tension & 3 & cross grain tension \\
\hline & 4 & cross grain tension & 4 & compression \& simple tension \\
\hline & 5 & compression & 5 & cross grain tension \\
\hline & 6 & cross grain tension & 6 & compression \& cross grain tension \\
\hline & 7 & cross grain tension & 7 & compression \& cross grain tension \\
\hline & 8 & simple tension & 8 & brash tension \& simple tension \\
\hline & 9 & brash tension & 9 & brash tension \& simple tension \\
\hline & 10 & simple tension & 10 & compression \& cross grain tension \\
\hline
\end{tabular}
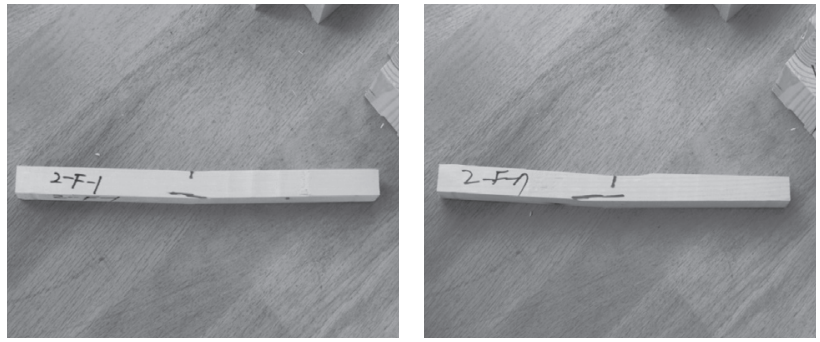

Fig. 6. Fracture mode of bending strength specimen for group 2 .

pression and cross grain tension occurred simultaneously. The next most common case was that of a simple tension fracture mode.

The failure types for compressive strength are all crushing failure types with the exception of the splitting failure type for specimen 7 in group 2.

\section{Statistical significance test of the mechanical properties between groups}

To determine if the results of each strength test from the two groups differed and in order to determine if they differed between the two groups, a variance analysis was conducted. The differences were tested to determine if they were significant at the level of 95 percent. Excel was used for statistical analysis. An F-test was conducted to verify whether the two groups have the

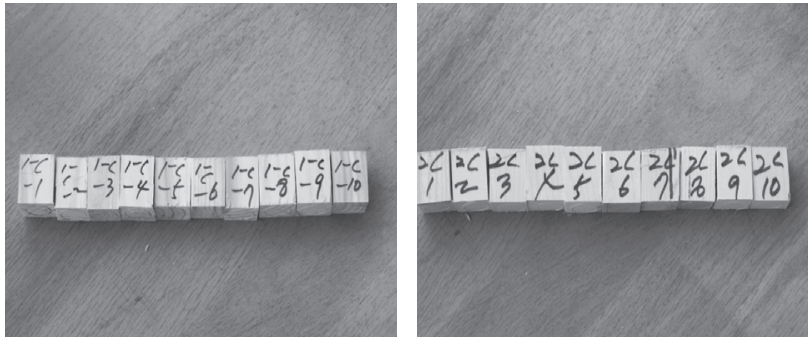

Fig. 7. Fracture modes of compressive strength specimens for groups 1 and 2

same variance prior to the $\mathrm{t}$-test. If the $\mathrm{p}$-value was less than 0.05 , heteroscedasticity should be assumed, otherwise homoscedasticity should be assumed. In the current study, all p-values for four mechanical properties exceeded 0.05 (See appendix A). A t-test was therefore conducted by assuming equal variance. For the t-test results, all p-values are larger than 0.05 (See appendix B). Therefore, there was no significant difference between the two groups in terms of mechanical properties.

However, there was an obvious visual difference between the two groups. Additional research is therefore required in order to estimate the residual strength from the data related to the existing domestic construction wood.

Appendixes A.

F-test result of compressive strength

Summary

\begin{tabular}{ccccc}
\hline Groups & Count & Sum & Average & Variance \\
\hline Column 1 & 10 & 352.9 & 35.29 & 38.64322 \\
Column 2 & 10 & 394.1 & 39.41 & 42.66544 \\
\hline
\end{tabular}

\begin{tabular}{|c|c|c|c|c|c|c|}
\hline Source of variation & SS & df & MS & $\mathrm{F}$ & P-value & $\mathrm{F}$ critical \\
\hline Between groups & 84.872 & 1 & 84.872 & 2.08765 & 0.165678 & 4.413873 \\
\hline Within groups & 731.778 & 18 & 40.65433 & & & \\
\hline Total & 816.65 & 19 & & & & \\
\hline
\end{tabular}


F-test result of tensile strength

Summary

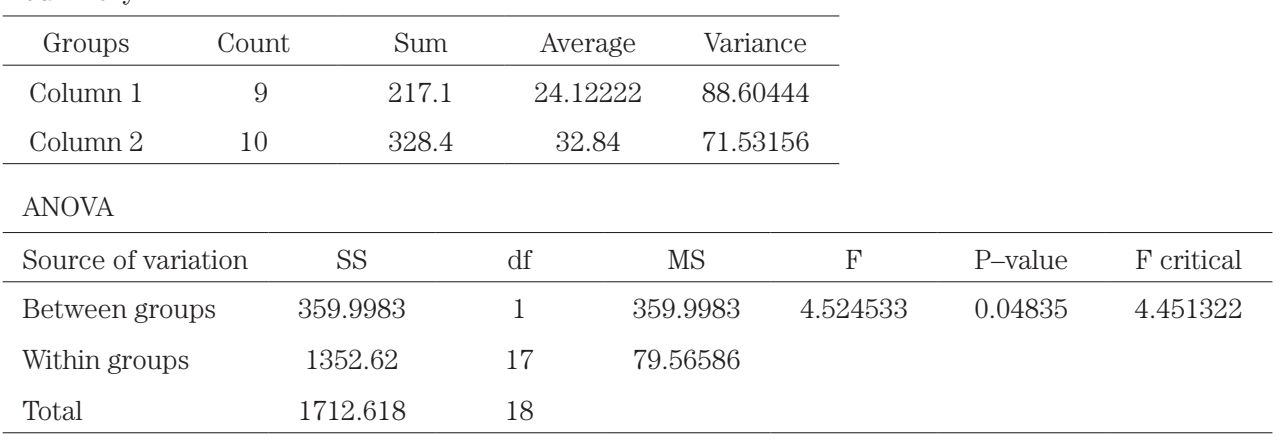

F-test result of bending strength

Summary

\begin{tabular}{ccccc}
\hline Groups & Count & Sum & Average & Variance \\
\hline Column 1 & 10 & 725.4 & 72.54 & 145.756 \\
Column 2 & 10 & 838.8 & 83.88 & 155.4751 \\
\hline
\end{tabular}

\begin{tabular}{lcccccc} 
ANOVA & \multicolumn{1}{l}{} \\
\hline Source of variation & SS & df & MS & F & P-value & F critical \\
\hline Between groups & 642.978 & 1 & 642.978 & 4.269001 & 0.053513 & 4.413873 \\
Within groups & 2711.08 & 18 & 150.6156 & & & \\
Total & 3354.058 & 19 & & & & \\
\hline
\end{tabular}

F-test result of shear strength

Summary

\begin{tabular}{ccccc}
\hline Groups & Count & Sum & Average & Variance \\
\hline Column 1 & 10 & 77.9 & 7.79 & 1.812111 \\
Column 2 & 10 & 74.2 & 7.42 & 0.197333 \\
\hline
\end{tabular}

\begin{tabular}{lcccccc} 
ANOVA & \multicolumn{1}{l}{} \\
\hline Source of variation & SS & df & MS & F & P-value & F critical \\
\hline Between groups & 0.6845 & 1 & 0.6845 & 0.681283 & 0.419951 & 4.413873 \\
Within groups & 18.085 & 18 & 1.004722 & & &
\end{tabular}

\section{Appendixes B.}

t-test result of compressive strength

t-test: (assuming equal variances)

\begin{tabular}{ccc}
\hline & Variable 1 & Variable 2 \\
\hline Mean & 35.29 & 39.41 \\
Variance & 38.64322 & 42.66544 \\
Observations & 10 & 10 \\
Pooled variance & 40.65433 & \\
Hypothesized Mean difference & 0 & \\
df & 18 & \\
$\mathrm{t}$ value & -1.44487 & \\
$\mathrm{P}(\mathrm{T}<=\mathrm{t})$ one-tail & 0.082839 & \\
$\mathrm{t}$ critical one-tail & 1.734064 & \\
$\mathrm{P}(\mathrm{T}<=\mathrm{t})$ two-tail & 0.165678 & \\
$\mathrm{t}$ critical two-tail & 2.100922 \\
\hline
\end{tabular}

t-test result of tensile strength

t-test: (assuming equal variances)

\begin{tabular}{ccc}
\hline & Variable 1 & Variable 2 \\
\hline Mean & 24.12222 & 32.84 \\
Variance & 88.60444 & 71.53156 \\
Observations & 9 & 10 \\
Pooled variance & 79.56586 &
\end{tabular}

Hypothesized Mean difference 0

17

$-2.12709$

0.024175

1.739607

0.04835

2.109816 


\begin{tabular}{ccc}
\multicolumn{3}{c}{ t-test result of bending strength } \\
t-test: (assuming equal variances) \\
\hline Mean & Variable 1 & Variable 2 \\
\hline Variance & 72.54 & 83.88 \\
Observations & 145.756 & 155.4751 \\
Pooled variance & 10 & 10 \\
Hypothesized Mean difference & 150.6156 & \\
df & 18 & \\
t value & -2.06616 & \\
$\mathrm{P}(\mathrm{T}<=\mathrm{t})$ one-tail & 0.026757 & \\
$\mathrm{~T}$ critical one-tail & 1.734064 \\
$\mathrm{P}(\mathrm{T}<=\mathrm{t})$ two-tail & 0.053513 & \\
$\mathrm{t}$ critical two-tail & 2.100922 & \\
\end{tabular}

\section{CONCLUSION}

Because studies associated with residual capacities for existing structures in Korea have not been conducted, this present study has been carried out. The case study building used for this research was the educational building of Iksan National College in Korea. The building has been used as a lecture hall since 1959. There were a total of 196 pieces used as sample specimens. These 196 rafters were visually divided into two groups according to annual ring and cross-section features. Although the sample sizes that were available in this study were rather small, the testing and analysis indicate that lumber recycled from this domestic school building has the potential to be reused in secondary members in wood-framed construction that does not require special safety standards and can be reprocessed as eco-interior or antique furniture materials.

From the results of this study, the following conclusions have been made:

1. The moisture content of group 1 was found to be higher than that of group 2. In the case of ovendried density, the averages between the two groups were almost the same.

2. The strength values of group 2 were all higher than those of group 1 with the exception of shear strength.

3. The main Fracture mode of group 1 is that of cross

\begin{tabular}{ccc}
\multicolumn{3}{c}{ t-test result of shear strength } \\
t-test: (assuming equal variances) & \\
\hline & Variable 1 & Variable 2 \\
\hline Mean & 7.79 & 7.42 \\
Variance & 1.812111 & 0.197333 \\
Observations & 10 & 10 \\
Pooled variance & 1.004722 & \\
Hypothesized Mean difference & 0 & \\
df & 18 & \\
t value & 0.825399 & \\
$\mathrm{P}(\mathrm{T}<=\mathrm{t})$ one-tail & 0.209975 & \\
$\mathrm{~T}$ critical one-tail & 1.734064 & \\
$\mathrm{P}(\mathrm{T}<=\mathrm{t})$ two-tail & 0.419951 & \\
$\mathrm{t}$ critical two-tail & 2.100922 & \\
\hline
\end{tabular}

grain tension. In the case of group 2, the fracture modes are distinguished by a mixed mode rather than by one type of mode. Failure types for compressive strength are all of a crushing failure type with the exception of the splitting failure type for specimen 7 in group 2.

4. There were no significant differences between the two groups in terms of mechanical properties. However, because there was an obvious visual difference between the two groups, additional research is required.

\section{REFERENCES}

ASTM D 143-94. Standard Test Methods for Small Clear Specimens of Timber

ASTM D2395-02 Standard Test Methods for Specific Gravity of Wood and Wood-Based Materials

ASTM D4442-92 Standard Test Methods for Direct Moisture Content Measurement of Wood and Wood-Base Materials

Fridley, K. J., Mitchell, J. B., Hunt, M. O., and Senft, J. F. 1996. Effect of 85 years of service on mechanical properties of timber roof members. Part 1. Experimental Observations. Forest Prod. J. 46(5): 72-78

Lanius, R. M., Tichy, R., and Bulliet, W. M. 1981. Strength of old joists. J. Of Struct. Engrg., ASCE, 107(12): 2349-2364

Rammer, D. R., and Lebow, P. K. 1997. Shear strength of unchecked Douglas-fir beams. J. of Matls. in Const., ASCE, 9 (3): 130-138 